\title{
CTSH Gene
}

National Cancer Institute

\section{Source}

National Cancer Institute. CTSH Gene. NCI Thesaurus. Code C28463.

This gene is involved in the degradation of lysosomal proteins. 